\title{
CRITICAL MOTIVATIONAL FACTORS FOR ENHANCING EMPLOYEE PERFORMANCE IN CONSTRUCTION FIRMS BASED ON CORRELATION AND PRINCIPAL COMPONENT ANALYSES
}

\author{
M. B. Zailani ${ }^{1, *}$, A. G. Ibrahim ${ }^{2}$ and Y. Bahago ${ }^{3}$ \\ 1, 2, 3, Department of Building, Ahmadu Bello University, ZARIA, KAdunA STATE, NIGERIA \\ E-mail addresses: ${ }^{1}$ bellomahmud34@gmail.com, ${ }^{2}$ getsomsc12012@gmail.com \\ 3 yahayabahago84@gmail.com
}

\begin{abstract}
Over the years, construction firms have often hinged their success on the effective motivation of their employees so as to ensure productivity and improved performance. Previous studies noted that various factors affect the motivational level of employees with regards to work performance. However, due to the difference in employee needs, not all motivational factors have influence on employees' performance. This study sets out to assess the influence of motivational factors on the performance of employees in construction firms. The study aim was achieved through the identification and assessment of critical motivational factors (intrinsic and extrinsic) in the Nigerian construction firms. Perceptual data was collected from employees of selected construction firms using a structured questionnaire. Data collected was analyzed using descriptive and inferential statistics. Motivational factors were ranked based on respective mean scores from the most to the least influential. Extrinsic motivational factors such as promotion when due, availability of resources and provision of transportation for employees were found to be the most influential factors on performance. Whereas, constant supervision was found to have the least influence on performance. Findings of the study provides construction firms with empirical data on factors that influence the motivation level of employees with a view to optimizing employee productivity. It is recommended that construction firms should pay close attention to the peculiar needs of respective employees which aids in optimizing organizational performance.
\end{abstract}

Keywords: Motivation, Employee performance, construction firms, critical factors

\section{INTRODUCTION}

Globalization and other related factors have largely influenced the dynamics of human resource management in organizations. Güngör [1] observed that organizations in this dynamic globalized world adopt various methods and techniques in developing and maintaining their human resources to enhance overall performance. Overtime, organizations like construction firms often hinge their successes to effective motivation of employees which ensures productivity and improved performance [2].

Certo, et al. [3] described motivation as giving people incentives that cause them to act in a desired way. It is the process of arousing and sustaining goal directed behavior amongst a group of people or workers [4]. In an organizational setting, motivation means ways to make subordinate to act in a desired manner in the interest of the organization or employer. Studies in organizational behavior and psychology have developed a variety of theories and approaches to human motivation with an effort to finding the determinants of motivation and performance in organizations.

The magnitude of an employee's performance that ultimately leads to favorable organizational performance is a key indicator of organizational success that should be given greater emphasis as it measures the competitive power of an organization $[5,6]$. Previous researches showed that employee motivation was one of the key factors which 
influences employee productivity and ultimately organizational performance [7-9]. Robbins, et al. [10] opined that employees' motivation at the work place appears through their willingness to effectively use their knowledge and skills to achieve the desired organizational objectives in relation to their satisfaction and needs. As the performance of employees is comprised of both motivation and capability, identification of favourable motivational factors by employers is critical in improving the capabilities of their workforce [11].

Zameer et al. [9] as well as a vast number of studies reported that there are several key elements which can enhance the commitment of employees towards an organization. These factors include salaries and wages, job security, promotion, bonus amongst others. Ivanivich, et al [12] noted that committed employee tend to receive motivation at the workplace and be rewarded for good achievements.

These studies ascertain that human beings have certain needs and desire while they continually strive to perform. More so, positively motivated individuals tend to perform better at work. However, the ability of organizations to identify distinct employee's needs and desires has been a major area of concern. Organizations find it difficult to employ the right motivational techniques due to the diversity of employee wants. Therefore, this study was focused or aimed at assessing the influence of various motivational factors in construction firms with a view to enhancing employees' performance. The study aim was achieved through the identification and assessment of critical motivational factors (intrinsic and extrinsic) in the Nigerian construction firms.

\subsection{Motivation}

The term "motivation" originated from the Latin word "movere" which means "to move" [13]. It builds on the word "motivation" that is an emotion or willingness to stimulate action in easy terms. In most cases, motivation has heavily relied on the derive and willingness to perform or act. Although motivation is majorly based on consciousness derived from within an individual, [14] noted that sometimes it can be externally induced. According to [15], motivation is the drive that forces or instigates employees to make a decision or action. Employees can either be positively motivated or negatively motivated depending on the circumstances. As such, various factors can largely influence the motivation level of employees in an organization. According to [16], these factors can be broadly categorized into two; "Extrinsic factors" and "Intrinsic factors".

Extrinsic factors emanate from tangible rewards that are external and partly beyond the control of the person or individual receiving them such as pay, retirement benefits, healthcare plan. Whereas intrinsic factors refer to motivation that emerges from within a person which include feelings of self-esteem, accomplishment, recognition amongst others. Most organizations employ one or more motivational techniques to elicit role compliance and goal directed behaviors from their employees. These motivational techniques are usually intended to maximize benefits to the organization, but their relative utility varies considerably amongst employees. No one works for free, nor should they. Employees want to earn reasonable salary/payment and employees desire their employers to feel that is what they are getting. Whereas, Intrinsic motive is an individual's willingness to do his / her job well to satisfy inherent requirements. In other words, a person conducts a job to attain certain kinds of inner states that experiences as an intrinsic motivation related to psychological rewards such as recognizing a finished task. External benefits like food, money, praise, and so on, are not the main reason for a person to engage in activities [17]. The job itself can satisfy intrinsic motives. The job is the primary source of motivation as it offers the person with interest, stimulation, difficulties, and possibilities for personal growth and accomplishment. Intrinsically driven conduct is the one determined by the need to feel skilled and selfdetermined by an individual. On the one hand, an individual will seek out challenges that allow him/her to behave in ways that provide him/her with a sense of competence and self-determination [18]. Most individuals are working to earn a living, but also because of other work-related satisfactions, such as doing meaningful things.

Extrinsic motives cannot only be satisfied by the work itself; it requires a reward system where the value in work is seen in a reward for that work. That means pleasure comes from something the task leads to, such as money. According to [19] the effects of work, as well as its contributing factors are also of importance for the need satisfaction. As a result, work is seen as a means to pursue other motives. Such extrinsic motives include monetary compensation/salaries, job enrichment, working environment and nature of work. All these and more 
can have significant effects on employees' motivation.

\section{METHODOLOGY}

A quantitative research approach was adopted for the study. The quantitative approach employs the use of mathematical and statistical techniques to identify facts and causal relationship between variables. Quantitative research investigates the "what, where and when" of decision making, and also, the results are often presented in models, tables and graphs [20]. Eleven small scale construction firms across three major cities in Northern Nigeria (Kaduna, Kano and Abuja) were selected to serve as the study population. These firms were selected based on a pilot survey which consisted of 10 firms from each city. The criteria for selection was number of employees less than 100 at the time of the survey. Perceptual data on the influence of distinct motivational factor on individual performance was randomly collected using a structured questionnaire. A letter of introduction was sent to the desk officers of each firm with regards to the study, as well as requesting permission to have access to the firm's data. All eleven firms responded positively, and a total of five hundred and six (506) employees where identified from the firms as the research sample frame. The number was further sampled to two hundred and twenty-three (223) using the [21] formula for sample size at $95 \%$ confidence level.

$\mathrm{n}=\frac{N}{1+N(e) 2}=\frac{506}{1+506(0.05) 2}=223$

where; $\mathrm{n}=$ Sample Size, $\mathrm{N}=$ Study population and e $=$ Level of precession

Data collected was analyzed using descriptive statistics. The reliability of the data was analyzed using the internal consistency method by calculating the Cronbach's Alpha which is the most popular test for internal consistency [22].

\section{RESULTS AND DISCUSSION}

\subsection{Response Rate and Reliability}

A total of 223 questionnaires were distributed to employees in respective construction firms. All but four (4) were successfully retrieved which represents $98.2 \%$ response rate as shown in figure 1 . According to [23], reliability indicates dependability, stability, predictability, consistency and refers to the extent to which a measuring procedure yields the same results in repeated trials. The reliability of data in this study was found be above the 0.70 threshold as presented in Table 1, as such reliable.

\subsection{Demography of respondents}

Studies have shown that the demography of respondents have a significant influence on the findings of studies of employees' motivation [5]. This is largely due to the distinct nature and wants of each employee. As such, it is important to address the demography of this study's respondents with a view to put the findings of the study into clear perspective. Due to their distinct peculiarities, motivational factors tend to differ between gender. Figure 1 shows the respondents gender distribution. A large percentage of the respondents were male representing $87.2 \%$ while only $12.8 \%$ of the respondents were female. This is majorly due to the fact that the construction industry is largely dominated by men.

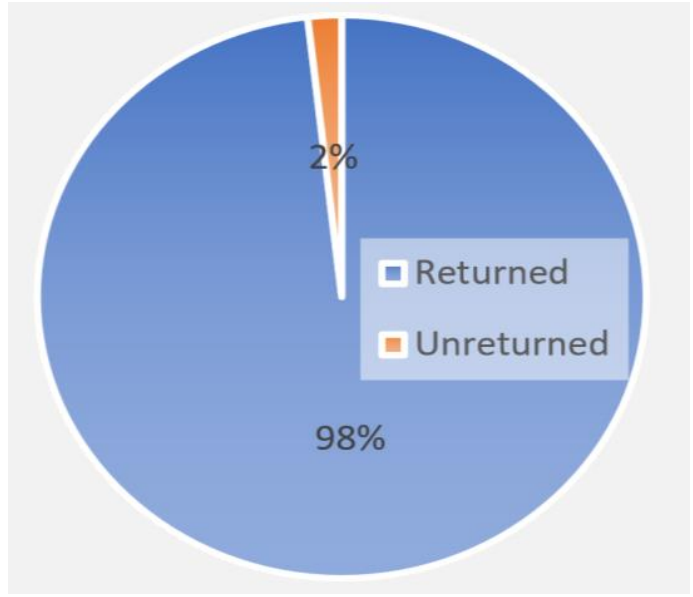

Fig 1: Response Rate

Table 1: Reliability Statistics

\begin{tabular}{ccc}
\hline $\begin{array}{c}\text { Cronbach's } \\
\text { Alpha }\end{array}$ & $\begin{array}{c}\text { Cronbach's Alpha } \\
\text { Based on } \\
\text { Standardized Items }\end{array}$ & N of Items \\
\hline 0.769 & 0.73 & 20 \\
\hline
\end{tabular}

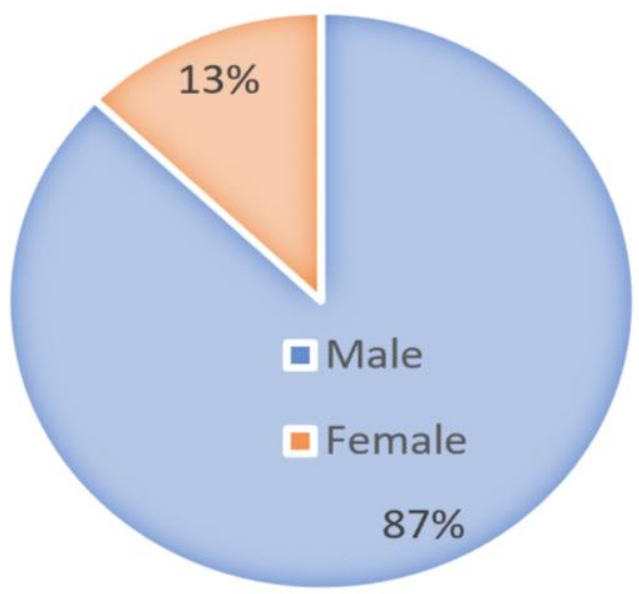

Fig 2: Gender Status

Vol. 39, No. 3, July 2020 
More so, the years of experience of an employee influences the motivational drives of that employee, as well as the overall motivational level. Veteran employees tend to be more driven by intrinsic factors as opposed to extrinsic factors. Figure 3 shows the work experience of the respondents with 54 respondents (representing $24.7 \%$ ) having their work experience between 1-10 years, 78 (representing $35.6 \%$ ) spent $11-20$ years in the industry, 67 (representing $30.6 \%$ ) having $21-30$ years of experience in the industry while 20 (representing $9.1 \%$ ) have $31-40$ years and above of experience in the industry.

\subsection{Influence of Motivational Factors on Employee's Performance}

Both intrinsic and extrinsic employee motivational factors were identified from literature and presented to the respondents on a Likert scale of 1-5 (where $1=$ No influence and $5=$ Highly influential). The respondents were required to rate their perceived influence level of each identified factor on their respective work performance. Table 4,5 and 6 shows the ranking of the factors based on respective mean scores as perceived by the employees.

Extrinsic motivational factors which include "promotion when due", availability of resources and provision of transportation ranked as the most influential factors on employees' performance with mean scores of 4.3 respectively. This is in line with the findings of Thomas and Velthouse [23], that employees take promotion as the ultimate achievement in their career and when it is realized, the employee feels extremely satisfied. Provision of accommodation by the firm to the employees was ranked $4^{\text {th }}$ with a mean score of 4.2 as perceived by the respondents. As shelter is one of the most pressing human needs, employees feel more motivated to concentrate on their respective work when they know that the need is satisfied [24]. Other extrinsic factors such as renumeration, provision of safety gears and free medical treatment were also ranked amongst the top influential factors with mean scores of 4.1 respectively. Good working environment ranked $8^{\text {th }}$ with a mean score of 3.9. Bonus scheme, provision of recreational facilities as well as working condition were found to have a relative influence on employee's performance having ranked $9^{\text {th }}, 10^{\text {th }}$ and $11^{\text {th }}$ respectively. Whereas, employee training, insurance and constant supervision with respective mean scores of 3.8, 3.7 and 3.6 were ranked to have the least influence on employee performance in construction firms.

Job security as well as recognition of work effort(s) at the work place were perceived to be the most influential intrinsic motivational factors with respective mean scores of 4.1. A sense of belonging which stems from the employer's ability to engage the employee with a degree of trust and autonomy ranked $3^{\text {rd }}$ with a mean value of 4.0. However, factors which include opportunity for skill development, challenging work and freedom in work place with respective mean scores of $3.9,3.7$ and 3.6 were perceived to have the least influence on employees in construction firms. Furthermore, taking a broader look at the influence of motivational factors on employees, Table 6 presents a ranking of both intrinsic and extrinsic motivational factors.

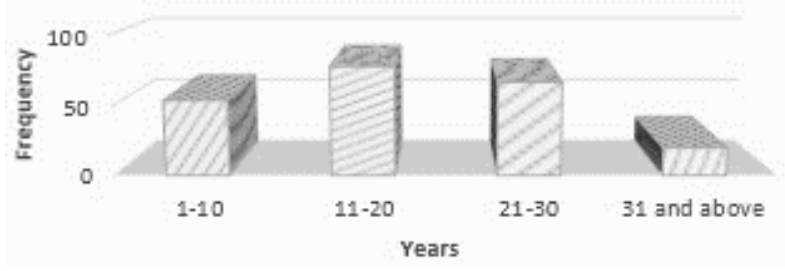

Fig 3: Years of Experience

Table 2: Influence of Extrinsic motivational factors on employee performance

\begin{tabular}{|c|c|c|c|}
\hline SN & Items & Mean & $\begin{array}{l}\text { Std. } \\
\text { Dv }\end{array}$ \\
\hline 1 & Promotion when due & 4.3 & 0.675 \\
\hline 2 & Availability of work tools/equipment & 4.3 & 0.949 \\
\hline 3 & Transportation & 4.3 & 1.252 \\
\hline 4 & Residential Accommodation & 4.2 & 0.919 \\
\hline 5 & Renumeration/salary & 4.1 & 0.738 \\
\hline 6 & Provision of safety gears & 4.1 & 0.876 \\
\hline 7 & Free Medical Treatment & 4.1 & 1.197 \\
\hline 8 & Good Working Environment & 3.9 & 0.738 \\
\hline 9 & Bonus Scheme & 3.8 & 0.632 \\
\hline 10 & $\begin{array}{l}\text { Provision of Recreation and } \\
\text { Relaxation Facilities }\end{array}$ & 3.8 & 0.789 \\
\hline 11 & Working condition & 3.8 & 0.919 \\
\hline 12 & Employees Training & 3.8 & 1.229 \\
\hline 13 & $\begin{array}{l}\text { Subsidized group/Personal } \\
\text { Insurance }\end{array}$ & 3.7 & 0.675 \\
\hline 14 & Constant Supervision & 3.6 & 0.966 \\
\hline
\end{tabular}

Table 3: Influence of Intrinsic motivational factors on employee performance

\begin{tabular}{llll}
\multicolumn{4}{c}{ on employee performance } \\
\hline SN & Items & Mean & Std. Dv \\
\hline 1 & Job Security & 4.1 & 0.994 \\
2 & Award/Recognition & 4.1 & 1.101 \\
3 & Sense of belonging & 4.0 & 0.471 \\
4 & Opportunity for skill Development. & 3.9 & 0.994 \\
5 & Challenging Work & 3.7 & 0.823 \\
6 & Freedom in Work Place & 3.6 & 0.516 \\
\hline
\end{tabular}


Extrinsic factors that include promotion when due, availability of resources and provision of transportation were ranked the highest with an average mean score of 4.3. Whereas, intrinsic factors that include job security and sense of belonging were the only factors ranked in the top ten (10) influential motivational factors with mean scores of 4.1 and 4.0 respectively. Opportunity for skill development ranked 13th with a mean score of 3.9. Whereas, challenging work and freedom in work place as intrinsic factors ranked amongst the least influential motivational factors on employee performance with mean scores of 3.7 and 3.6 respectively.

Despite some of the factors having relatively low mean scores compared to others, (as presented in Table 6, with factors ranked $11^{\text {th }}$ to $20^{\text {th }}$ having mean scores lower than 4.0), it is imperative to note that all factors have mean scores above the mid-scale point of 2.5. This translates to all factors having relative influence on employee motivation in Nigerian construction firms. The joint least ranked factors which include freedom in work place and constant supervision both had mean scores of 3.6 which is farfetched from the mid-scale point.

To further ascertain the critical motivational factors on employee productivity in construction firms, a Principal Component Analysis (PCA) was carried out using SPSS $\AA$ as done in similar studies [25]. The factors as shown in Table 5 were classified into two (2) fixed major components using the Verimax rotation method with Kaiser Normalization; rotation converged in 3 iterations. Result of the PCA shows that the extracted components can explain a cumulative $71.6 \%$ of the cases of employee motivation in construction firms. Table 6 shows the rotated component matrix for the two (2) components.

The first component was majorly influenced by extrinsic motivational factors. These factors include salary/renumeration, availability of tools/equipment, accommodation, provision of safety gears, transportation and job security. This component explains $44.4 \%$ of the variance on the effect of employee motivation on productivity in construction firms. Monetary benefits play very important role in motivation and performance [26]. In [27] it was stated that monetary rewards create a positive environment and develop job interest which results in increased employee performance.
Table 4: Influence Level of Motivational Factors on Employee Performance (Overall)

\begin{tabular}{|c|c|c|c|}
\hline SN & Items & Mean & Std. Dv \\
\hline ME1 & Promotion when due & 4.3 & 0.675 \\
\hline ME2 & $\begin{array}{l}\text { Availability of work } \\
\text { tools/equipment }\end{array}$ & 4.3 & 0.949 \\
\hline ME3 & Transportation & 4.3 & 1.252 \\
\hline ME4 & Residential Accommodation & 4.2 & 0.919 \\
\hline ME5 & Renumeration/salary & 4.1 & 0.738 \\
\hline ME6 & Provision of safety gears & 4.1 & 0.876 \\
\hline Ml1 & Job Security & 4.1 & 0.994 \\
\hline MI2 & Award/Recognition & 4.1 & 1.101 \\
\hline ME7 & Free Medical Treatment & 4.1 & 1.197 \\
\hline MI3 & Sense of belonging & 4.0 & 0.471 \\
\hline ME8 & Good Working Environment & 3.9 & 0.738 \\
\hline Ml4 & $\begin{array}{l}\text { Opportunity for skill } \\
\text { Development. }\end{array}$ & 3.9 & 0.994 \\
\hline ME9 & Bonus Scheme & 3.8 & 0.632 \\
\hline ME10 & $\begin{array}{l}\text { Provision of Recreation and } \\
\text { Relaxation Facilities }\end{array}$ & 3.8 & 0.789 \\
\hline ME11 & Working Condition & 3.8 & 0.919 \\
\hline ME12 & Employees Training & 3.8 & 1.229 \\
\hline ME13 & $\begin{array}{l}\text { Subsidized group/Personal } \\
\text { Insurance }\end{array}$ & 3.7 & 0.675 \\
\hline Ml5 & Challenging Work & 3.7 & 0.823 \\
\hline Ml6 & Freedom in Work Place & 3.6 & 0.516 \\
\hline ME14 & Constant Supervision & 3.6 & 0.966 \\
\hline
\end{tabular}

Table 5: Principal Component Analysis

\begin{tabular}{llll}
\hline Component & \multicolumn{3}{l}{ Initial Eigenvalues } \\
\hline & Total & $\%$ of Variance & Cumulative \% \\
1 & 8.883 & 44.417 & 44.417 \\
2 & 5.436 & 27.178 & 71.596 \\
3 & 3.298 & 16.49 & 88.085 \\
4 & 0.922 & 4.609 & 92.695 \\
5 & 0.56 & 2.799 & 95.494 \\
6 & 0.394 & 1.971 & 97.465 \\
7 & 0.277 & 1.387 & 98.852 \\
8 & 0.198 & 0.99 & 99.842 \\
9 & 0.032 & 0.158 & 100 \\
10 & $8.93 \mathrm{E}-16$ & $4.46 \mathrm{E}-15$ & 100 \\
11 & $6.37 \mathrm{E}-16$ & $3.18 \mathrm{E}-15$ & 100 \\
12 & $3.66 \mathrm{E}-16$ & $1.83 \mathrm{E}-15$ & 100 \\
13 & $2.66 \mathrm{E}-16$ & $1.33 \mathrm{E}-15$ & 100 \\
14 & $1.61 \mathrm{E}-16$ & $8.03 \mathrm{E}-16$ & 100 \\
15 & $3.91 \mathrm{E}-17$ & $1.96 \mathrm{E}-16$ & 100 \\
16 & $-1.73 \mathrm{E}-16$ & $-8.67 \mathrm{E}-16$ & 100 \\
17 & $-3.47 \mathrm{E}-16$ & $-1.73 \mathrm{E}-15$ & 100 \\
18 & $-4.99 \mathrm{E}-16$ & $-2.49 \mathrm{E}-15$ & 100 \\
19 & $-7.00 \mathrm{E}-16$ & $-3.50 \mathrm{E}-15$ & 100 \\
20 & $-1.01 \mathrm{E}-15$ & $-5.07 \mathrm{E}-15$ & 100 \\
\hline
\end{tabular}


Table 6: Rotated Component Matrix

\begin{tabular}{lll}
\hline & Component \\
\hline ME5 & $\mathbf{1}$ & $\mathbf{2}$ \\
ME2 & $\mathbf{0 . 9 5 5}$ & -0.13 \\
ME4 & $\mathbf{0 . 9 5 4}$ & 0.195 \\
ME3 & $\mathbf{0 . 9 2 5}$ & -0.266 \\
ME6 & $\mathbf{0 . 8 9 8}$ & 0.222 \\
MI3 & $\mathbf{0 . 8 8 2}$ & -0.376 \\
MI1 & -0.864 & 0.036 \\
MI2 & $\mathbf{0 . 8 5 4}$ & -0.335 \\
ME1 & 0.683 & -0.461 \\
MI5 & 0.626 & 0.467 \\
ME11 & 0.586 & 0.583 \\
ME10 & -0.502 & 0.374 \\
MI4 & -0.491 & 0.045 \\
ME14 & 0.094 & $\mathbf{0 . 8 4}$ \\
MI6 & 0.36 & $\mathbf{0 . 8 3 3}$ \\
ME13 & -0.506 & $\mathbf{0 . 8 1 7}$ \\
ME7 & -0.428 & $\mathbf{0 . 8 1 7}$ \\
ME8 & 0.355 & -0.809 \\
ME9 & -0.214 & $\mathbf{0 . 7 5 6}$ \\
ME12 & 0.241 & 0.699 \\
\hline & -0.229 & 0.482 \\
\hline
\end{tabular}

The second component which explains $27.2 \%$ of the variance in employee motivation was influenced by both intrinsic and extrinsic factors. The intrinsic factors include opportunity for skill development and freedom in workplace. Whereas, the extrinsic factors are constant supervision, subsidized insurance and good working environment. This could be seen in line with the findings of [28] that motivated employees find the meaning, importance and purpose of their work in view of personal and social development.

\section{CONCLUSION}

This study set out to assess the influence level of distinct motivational factors on employee performance in construction firms. Findings of the study shows that extinctic motivational factors have more influence on employee performance than intrinsic factors. Promotion when due ranked as the most perceived influential motivational factors while constant supervision ranked the least. Job security, award/recognition as well as a sense of belonging were perceived to be the most intrinsic motivational factors. More so, it can be inferred from the PCA result that a decent reward for labour (salary/renumeration), coupled with the right tools/ equipment significantly motivates employees and has a positive effect on their respective performance. This shows that although intrinsic factors do lead to increase in motivational level, they have little or no influence on employee performance. Regardless, it is important to note that this finding is limited by the nature of factors identified in the study, as most of them are extrinsic factors. Furthermore, as stated earlier, demographic factors have significant effect on influence of various motivational factors on employee's performance. Although the years of experience of the respondents is relatively proportionate, the study respondents were largely dominated by men, this demographic representation should be rightly noted to put the findings in better perspective. It is recommended that construction firms should pay attention to the peculiarities of their employees in the adoption of motivational techniques with a view to optimizing organizational performance.

\section{REFERENCES}

[1] P. Güngör, "The relationship between reward management system and employee performance with the mediating role of motivation: A quantitative study on global banks," ProcediaSocial Behav. Sci., 2011.

[2] J. Hanaysha and M. Majid, "Employee Motivation and its Role in Improving the Productivity and Employee Motivation and its Role in Improving the Productivity and Organizational Commitment at Higher Education Institutions," J. Entrep. Bus., vol. 6, no. 1, pp. 17-28, 2018.

[3] S. T. Certo, J. R. Busenbark, H. S. Woo, and M. Semadeni, "Sample selection bias and Heckman models in strategic management research," Strateg. Manag. J., vol. 37, no. 13, pp. 26392657, Dec. 2016.

[4] J. Campbell and D. Nelson, "Principles of Organizational Behavior: Realities and Challenges," South West. Cengage, 2013.

[5] J. Hanaysha, "Testing the effects of employee empowerment, teamwork, and employee training on employee productivity in higher education sector" International Journal of Learning and Development, 6(1), 164-178, 2016.

[6] M. K. Soltani, "The relationship between quality of work life and employee productivity general administration of sport and youth Sistan and Baluchestan Province" The Social Sciences, 11(10), 2642-2647, 2016.

[7] B. J. Osabiya, "The effect of employees' motivation on organizational performance" 
Journal of Public Administration and Policy Research, 7(4), 62-75, 2015.

[8] P. Singh, "Increasing productivity with motivation in the workplace. National Monthly Refereed Journal of Research in Commerce \& Management, 2(6), 27-32, 2013.

[9] H. Zameer, S. Ali, W. Nisar, \& M. Amir, "The impact of the motivation on the employee's performance in beverage industry of Pakistan" International Journal of Academic Research in Accounting, Finance and Management Sciences, 4(1), 293-298, 2014.

[10] S. P. Robbins, T. A. Judge, A. Odendaal, G. Roodt, "Organisational behaviour: Global and South African perspectives". Cape Town, 2009.

[11] A.A. Katou, "How does human resource management influence organisational performance? An integrative approach based analysis" International Journal of Productivityand Performance Management, 66(6), 2017.

[12] J.M. Ivanivich, A.D. Szilagyi, and M. Wallace Jr. "Organizational Behavior and Perfor- mance" Santa Monica, CA: Goodyear Publishing Company Inc., p. 162, 1997.

[13] N. P. Ikechukwu, R. I. Hart, J. I. N. Ezeh, I. Bridget, and A. Jude-Peters, "Employee Motivation and Job Performance of Selected Construction Companies in Rivers State," Int. J. Eng. Manag. Res., 2019.

[14] E. Locke, "Toward a theory of task motivation and incentives," Organ. Behav. Hum. Perform., 1968.

[15] S. Hutchinson, Performance management: theory and practice. 2013.

[16] E. Deci and R. Ryan, "Intrinsic and extrinsic motivations: Classic definitions and new directions," Contemp. Educ. Psychol., 2000.

[17] R. Benabou and J. Tirole, "Intrinsic and extrinsic motivation," Rev. Econ. Stud., 2003.

[18] M. Grawitch and L. Barber, "Are You Focusing on Both Employee and Organizational
Outcomes," Organ. Heal. Initiat., 2009.

[19] K. Khan, S. Farooq, and M. Ullah, "The relationship between rewards and employee motivation in commercial banks of Pakistan," Res. J. Int. Stud., 2010.

[20] S. Rajasekar, P. Philominathan, V. Chinnathambi, "Research Methodology" Tamilnadu, India.2013.

[21] T. Yamane, Statistics: An introductory analysis. Prancticed Hall, UK, 1973.

[22] C. Forza, "Survey research in operations management: a process-based perspective" International Journal of Operations \& Production Management:; 22:152-94, 2002.

[23] K. W. Thomas and B. A. Velthouse, "Cognitive Elements of Empowerment: An 'Interpretive' Model of Intrinsic Task Motivation," Acad. Manag. Rev., vol. 15, no. 4, pp. 666-681, Oct. 1990.

[24] A. Saad and J. B. Elballa, "The Effect of Motivation on Productivity in the Sudanese Construction Industry," J. Eng. Comput., 2019.

[25] J. Varajão and M. M. Cruz-cunha, "Main motivations for CRM adoption by large Portuguese companies - a Principal Component Analysis," Procedia - Procedia Comput. Sci., vol. 100, pp. 1269-1279, 2016.

[26] H. Aguinis, H. Joo, \& R. K. Gottfredson, "What monetary rewards can and cannot do: How to show employees the money". Business Horizons, 56(2), 241-249, 2013.

[27] A. Beretti, C. Figuie'res, \& G. Grolleau, "Using money to motivate both 'saints' and 'sinners': A field experiment on motivational crowding-out". Kyklos, 66(1), 63-77, 2013.

[28] V. Vuori, \& J. Okkonen, "Knowledge sharing motivational factors of using an intraorganizational social media platform|. Journal of Knowledge Management, 16(4), 592-603, 2012. 